\title{
Improvement of the methods of assessing the influence of external factors on the strengths and weaknesses of the enterprise
}

\author{
Yriij Lozovik ${ }^{1, *}$, Bogdan Tishkov ${ }^{1, * *}$, Oksana Pomazun ${ }^{1, * * *}$, Vasily Derbentsev ${ }^{1, * * * *}$, and Alexey Hostryk ${ }^{2, \dagger}$ \\ ${ }^{1}$ Kyiv National Economic University named after Vadym Hetman, 54/1 Peremogy Ave, Kyiv, 03057, Ukraine \\ ${ }^{2}$ Odessa National Economic University, 8 Preobrazhenskaya Str., Odessa, 65082, Ukraine
}

\begin{abstract}
In the article considered the issues of constructing a classic SWOT analysis matrix, forming a list of key factors of the external and internal environment to assess the degree of their impact on the activities of real enterprises of Ukraine, improving the method of conducting SWOT analysis through the use of scientifically based scales and indicators. The thesis justified that SWOT analysis and other classic strategic management tools are conceptually described, and their use causes many approaches to their mathematical formalization and use. We propose our own approach to quantifying the strengths and weaknesses of the enterprise, external threats and opportunities at the main ten stages. The focus is on step-by-step calculation of integrated indicators for the main groups of SWOT analysis and their qualitative interpretation. Examples of implementation of SWOT analysis for a real enterprise are given. The company's strengths and weaknesses were identified. External capabilities and threats were analyzed. To assess the importance of indicators, a pairwise comparison technique was used, which provides for the estimation of indicators based on the average geometric value according to T. Saati. This made it possible to prioritize factors within the SWOT analysis methodology. Four quadrants are filled at the intersection of strengths/weaknesses, opportunities/threats and four types of potential strategies for the enterprise are described in the field defining: guidelines for the strategic development of the company; strategic advantages of the company; guidelines for the internal transformation of the enterprise; Limiting strategic development. Using a quantitative approach made it possible to build a SPACE matrix of strategy selection.
\end{abstract}

\section{Introduction}

An important tool of enterprise management at the stage of strategic planning is to identify and study the available internal and external resources, study the main opportunities and threats that may have a positive and negative impact on the studied enterprise. The lack of constant control over the factors of the environment of the enterprise leads to subjectivity and ambiguity of decisions, which creates significant uncertainty and risks in business. There is a need to improve the current methodology of strategic management.

The classical method of SWOT analysis greatly simplifies the reality and is aimed at one-time diagnosis of the enterprise environment, its capabilities and threats. It is most often used using brainstorming techniques, which leads to considerable subjectivity. In addition, the list of factors may differ significantly in different sectors of the economy. There is a need for a scientifically sound approach to setting up a model that can generate source information in the form of quantitative and qualitative data, can normalize them, process different types of data and

\footnotetext{
*e-mail: yuralm@ukr.net

**e-mail: tishcov_b@ukr.net

***e-mail: oksp@ukr.net

****e-mail: derbv@kneu.edu.ua

†e-mail: alexeyGostrik@gmail.com
}

work with different amounts of information. The use of incomplete and untimely information, sometimes even distorted information, leads to a significant violation of the quality of the model. At the same time, existing practice proves that the effectiveness of these methods of strategic management depends on the experience and intellectual potential of analysts, who actually play a key role in the quality of the study. Given that the head also acts as an expert, there is another problem regarding the adequacy of the study of available information and the correctness of the management decisions made by him based on the results of the analysis.

We have proposed our own approach to solving the problem of improving the classical SWOT analysis through the formation of a database of indicators, which is determined at the beginning of the study and can always be supplemented and improved. We also proposed a new stage and technology for determining the weight values and the formation of a qualitatively new model of SWOT analysis in order to process and analyze the factors of neutral, positive and negative effects. The developed measures are aimed at solving the problem of constant monitoring of the external environment of the enterprise, which can be integrated over time into the information system of enterprise management. It is expected that this will allow 
managers to develop operational and timely strategies for businesses.

Identification of key strengths and weaknesses of enterprises, external and internal factors of influence should be carried out using the classic tools of strategic management, which have gained wide popularity among marketers and strategists. Despite their more than half a century history, some of them have become classics, however these tools are described conceptually, their use leads to many approaches to their mathematical formalization and usage. The analysis of scientific works of domestic and foreign researchers dealing with SWOT analysis showed that the method has advantages and disadvantages. Since enterprises in different industries have different lists of factors and their weight, it is not possible to form a universal list of factors for evaluation.

\subsection{Brief literature review}

SWOT analysis is one of the most common methodologies for analysing the activities of the enterprise, which is the subject of many publications [1-8]. The classical theory of development of SWOT analysis methodology is constantly evolving. In the works $[9,10]$ a list of general factors without reference to a particular field is given. In the work of P. Mikhnenko [9] an attempt was made to build a dynamic modification of the SWOT analysis.

Currently, SWOT analysis remains one of the most popular tools of strategic management, which is often used at the stage of strategic planning for enterprises in various sectors of the economy. In particular, the works of well-known scientists include work on resource assessment, study of the main opportunities and threats, both for enterprises of traditional sectors of the economy, and for the evaluation of educational institutions, hospitals and other social facilities. The works are aimed to study the current situation and prospects for the development of various enterprises. In [11] a new SWOT model for digital ecosystem methodologies is proposed, in which the business and organizational issues, challenges and priorities are addressed. In [12] presented report on SWOT and PEST analyzes for implementation of reuse practices according to SuWaNu Program. In [13] the authors show the use of SWOT for a systematic analysis of the COVID-19 epidemic prevention.

The main purpose of the paper [14] is to present the rationale, the methodological details and a practical example of the application of the enhanced SWOT analysis in the context of technological foresight. The authors take into account and propose an innovative extension of SWOT analysis by an additional dimension: the assessment of factor significance in two time perspectives: the current state and the hypothetical horizon. As a result, a thirtytwo-field SWOT diagram is obtained. The paper alsopresents the practical implications of the proposed methodology by offering a case study.

Scientists have paid attention to the improvement of methods of SWOT analysis, detailing the influence of factors and their quantitative assessment in the recent publications $[15,16]]$ but the issues of qualitative SWOT anal- ysis remain relevant today. In particular, the lack of a unique approach to the description of factors, evaluation of weights and selection of scales for quantitative measurement and conclusion of the study leads to different modifications of these conceptual models and improvement of methods of strategic business analysis, identification of strengths and weaknesses [14, 15], a description of the situation in the industry [16] and determine the impact of major counter-parties on the diagnostic company and the industry as a whole.

Analysis of the development of the methodology shows that modern approaches to management provide opportunities for the application of advanced methods of SWOT analysis, in particular with the use of modern mathematical methods of modelling [17].

\subsection{The purpose and objectives of the study}

The purpose of the study is to improve the well-known and popular model SWOT analysis for assessing the strengths and weaknesses of the enterprise, its external capabilities and threats through the use of scientifically sound scales and indicators, which, in turn, will allow future users to reduce the time for analytical research and get quality conclusions and proposals (strategies) for the development of the enterprise.

To achieve this goal, the following tasks are formulated:

1. To improve the main stages of SWOT analysis for continuous monitoring of the impact of internal and external factors on the enterprise.

2. To identify a standard set of factors for assessing the internal and external environment.

3. To make a choice of scientifically substantiated scales and weight values of an estimation of the basic indicators for construction of mathematical model and its use for a substantiation of strategy of the enterprise.

4. To provide for the assessment of factors taking into account neutral, strong and weak action.

5. To test the proposed method of SWOT analysis on the example of a Ukrainian brewery.

\section{Methodology}

\subsection{SWOT analysis}

SWOT analysis today can be attributed to the classic tools of strategic management. In the first concept, strategic analysis was called SOFT analysis, in which existed and expected positive external factors were collected in Satisfactory and Opportunity clusters, and internal - in Fault and Threat clusters. The transition from SOFT to SWOT is not semantic, but conceptual, because its essence is the transition from the interface "good - bad" to the interface "internal-external". This methodological concept 
of strategic marketing analysis was first tested by Albert Humphrey [18]. The main elements of SWOT analysis are: Strengths, Weaknesses, Opportunities, Threats.

More than half of a century of history of this very popular tool and the accumulated experience of marketing research vast experience, include a number of significant changes in SWOT analysis, allow you to more effectively perform strategic business analysis.

The technology (algorithm) of SWOT analysis involves: first, the construction of a matrix, and secondly, the development of business strategies. At the intersection of exogenous and endogenous factors, the strategy and risks for the studied enterprise are determined.

In the scientific works which were analysed the sequence of SWOT analysis was as follows [1, 2, 4, 5]:

Stage 1. Formation of a hierarchy of indicators by groups of SWOT analysis.

Stage 2. Selection of scientifically sound scales and weight values are to assess the main indicators by groups.

Stage 3. Calculations and construction of a consolidated matrix of SWOT analysis. Defining guidelines for strategic development.

Stage 4. Development of strategies aimed at mitigating the effects of negative factors and strengthening the strengths of the enterprise.

Stage 5. Evaluation and control of the achieved results of the enterprise.

The above phasing of the SWOT analysis does not involve the formation of a database of key factors that may have different degrees of influence in the dynamics and has a number of problems with the assessment of neutral factors. A whole group of indicators that need constant monitoring is ignored. Therefore, we propose to supplement the methodology with new stages and tasks. The main stages of the SWOT analysis include the following ten stages:

Stage 1. Formation of the general base of factors for an estimation of groups of internal and external environment. Estimation of weights.

Stage 2. Definition of criteria (norms) of conformity on the given factors.

Stage 3. Assessment of internal factors in relation to deviations from the set norms (division of factors into neutral, strong and weak).

Stage 4. Assessment of external factors in relation to deviations from the set norm (division of factors into neutral, opportunities and threats).

Stage 5. Formation of a hierarchy of indicators by groups of SWOT analysis.

Stage 6. Selection of scientifically sound scales and weight values for evaluation of key indicators by groups.

Stage 7. Definition of strategic landmarks in development.

Stage 8. Carrying out calculations and construction of the consolidated matrix of SWOT analysis.

Stage 9. Development of strategies aimed at mitigating the effects of negative factors and strengthening the strengths of the enterprise.

Stage 10. Evaluation and control of the achieved results of the enterprise.
This approach provides an opportunity to conduct a SWOT analysis not once, but in the dynamics - tracking changes in key factors. The methodology must begin with the identification of all possible factors of influence from the internal and external environment and evaluation.

\subsection{Mathematical description}

For a mathematical description of the proposed approach to quantify the indicators of SWOT analysis, we introduce the following notation:

$I F_{i(j)}-(j)$ is the factor of the $i$ group of the internal environment $I F$.

$E F_{i(j)}-(j)$ is the factor of the $i$ group of the external environment $E F$.

The weight values of estimates of all factors of the internal / external environment, respectively $100 \%$ :

$$
\sum_{(j)} W_{i(j)}=1 .
$$

Depending on the actions of all the factors of the internal environment $(I F)$ on the studied enterprise, we propose to divide into three groups:

- neutral $I F^{(0)}$;

- strengths $I F^{(+)}$;

- weaknesses of $I F^{(-)}$.

Depending on the actions of environmental factors $(E F)$ on the studied enterprise, they can be divided into three groups:

1) neutral $E F^{(0)}$;

2) positive influence (opportunities) $E F^{(+)}$,

3) negative impact (threat) $E F^{(-)}$.

To assess only the strengths / weaknesses of the company, it is advisable to list the weight values for these groups, so that their share was $100 \%$.

$$
\begin{aligned}
& I F_{i(j)}^{(+) *}=\frac{w_{i(j)}^{(+)}}{\sum_{(j)} w_{i(j)}^{(+)} I F_{i(j)}^{(+)}} ; \\
& I F_{i(j)}^{(-) *}=\frac{w_{i(j)}^{(-)}}{\sum_{(j)} w_{i(j)}^{(-)} I F_{i(j)}^{(-)}} .
\end{aligned}
$$

Where to get:

$$
\begin{aligned}
& I F^{(+)}=\sum_{i} \sum_{(j)} I F_{i(j)}^{(+) *} ; \\
& I F^{(-)}=\sum_{i} \sum_{(j)} I F_{i(j)}^{(-) *} .
\end{aligned}
$$

This recalculation will allow the interpretation of integrated indicators of certain groups within certain research scales. 
To assess the opportunities / threats of the environment, we calculate the weight values for these groups, so that their share was $100 \%$.

$$
\begin{aligned}
& E F_{i(j)}^{(+) *}=\frac{w_{i(j)}^{(+)}}{\sum_{(j)} w_{i(j)}^{(+)} E F_{i(j)}^{(+)}} ; \\
& E F_{i(j)}^{(-) *}=\frac{w_{i(j)}^{(-)}}{\sum_{(j)} w_{i(j)}^{(-)} E F_{i(j)}^{(-)}} .
\end{aligned}
$$

And:

$$
\begin{aligned}
& E F^{(+)}=\sum_{i} \sum_{(j)} E F_{i(j)}^{(+) *} ; \\
& E F^{(-)}=\sum_{i} \sum_{(j)} E F_{i(j)}^{(-) *} .
\end{aligned}
$$

Calculation of the balance between the strengths $\left(I F^{(+)}\right)$and weaknesses $\left(I F^{(-)}\right)$of the internal environment which is carried out without taking into account the action of neutral factors:

$$
I F=I F^{(+)}-I F^{(-)}
$$

Under this approach, the share of factors of strengths and weaknesses should be $100 \%$, so the values of the weights of the relevant group of indicators (strong or weak action) should be adjusted to the total value of weights for these two groups.

Similarly, the balance between the external capabilities of $\left(E F^{(+)}\right)$and the threats to $\left(E F^{(-)}\right)$of the environment is calculated based on the following equation:

$$
E F=E F^{(+)}-E F^{(-)}
$$

\section{Empirical results}

\subsection{Factors for assessing the internal and external environment of the enterprise}

According to the results of research of basic factors for the assessment of the internal environment of the enterprise, also a list of the most used was formed, presented in table 1 .

The following list of key factors for assessing the degree of environmental impact on the enterprise is shown in table 2 .

Since the list of factors is quite large (more than 30 factors for the assessment of the internal environment and more than 20 - for the external), the application of the method of pairwise comparisons, Fishburn's method or other methods of setting weights becomes problematic. The solution of such a problem is possible through the decomposition of factors in new subsystems. To distribute the factors influencing the internal environment of the enterprise, we provide the allocation of such subsystems as: innovation and development, logistics, production, sales and promotion, enterprise finance, personnel management and subsystems of strategic and tactical management. And to assess environmental factors, it is proposed to use two subsystems: intermediate environmental factors and macro environment.

\subsection{Determination of weights by the method of pairwise comparisons}

Using the method of analysis of hierarchies by T. L. Saati[17] allows you to distribute the factors in these groups, to determine the weight of each subsystem, and the factors themselves within these groups. The transition from a two-level hierarchy to a one-level one using linear convolution is achieved by multiplying the weight value of a certain factor by the weight value of its subsystem. This will determine the weight of all factors within the internal / external environment. Note that the number of levels of indicators is determined by the objectives of the study. Different indicators of $F_{i j}$ have their significance in the system of SWOT analysis. Determination of weights $\left(w_{i}\right)$ should be carried out by the method of pairwise comparisons by T. L. Saati. Its essence is to establish weights based on a system of pairwise comparisons of indicators with each other. We calculate the weights for certain groups of indicators, which involves comparing the indicators with each other on the following 5-level scale: 1 - EI (equally important), 2 - SA (slight advantage), 3 BA (big advantage), 4 - HA (huge advantage), 5 - MA (maximum advantage).

Inversely proportional estimates between indicators are as follows: $1 / 2=0.5\left(S A^{-1}\right) ; 1 / 3=0.33(3)\left(B A^{-1}\right)$; $1 / 4=0.25\left(H A^{-1}\right) ; 1 / 5=0.2\left(M A^{-1}\right)$.

Table 3 shows the calculation of weights by internal factors of the subsystem "Innovation and Development" $\left(F_{1}\right)$.

Similarly, weights were obtained for other groups of indicators of internal and external environment. The results of calculations of weights for groups of factors of the external environment are shown in table 4 and the internal environment in table 5.

\subsection{Weights of indicators of the internal environment}

The use of linear convolution allows the weight values of indicators within the studied subsystems to be converted into weight values of indicators within a single system of internal indicators (table 6).

\subsection{Weights of environmental indicators}

Similarly, make the transition from a two-level hierarchy to a one-level hierarchy of weights of the environment (table 7).

In the second stage, researchers will be able to assess these factors in terms of their deviation from the norm. Deviations in the study process can be neutral (in case of compliance with the norm), or have negative and positive deviations. This assessment allows us to divide the factors into three groups:

- neutral;

- strengths;

- weak sides. 
Table 1. List of factors for assessing the internal environment of the enterprise

\begin{tabular}{|c|c|c|}
\hline The name of the factor $I F_{i(j)}$ & Strengths, $I F_{i(j)}^{(+)}$ & Weak sides, $I F_{i(j)}^{(-)}$ \\
\hline \multicolumn{3}{|c|}{ Subsystem "Innovation and Development" $\left(I F_{1}\right)$} \\
\hline $\begin{array}{l}\text { Experience in developing new } \\
\text { products and brands, } I F_{1(1)}\end{array}$ & $\begin{array}{l}\text { Significant experience in developing } \\
\text { new products and brands }\end{array}$ & $\begin{array}{l}\text { Lack of experience in developing new } \\
\text { products and brands }\end{array}$ \\
\hline $\begin{array}{l}\text { Reputation and image of the com- } \\
\text { pany, } I F_{1(2)}\end{array}$ & $\begin{array}{l}\text { Good reputation and image of the com- } \\
\text { pany }\end{array}$ & $\begin{array}{l}\text { Insufficient reputation and image of the } \\
\text { company }\end{array}$ \\
\hline $\begin{array}{l}\text { Accreditation and certification, } \\
I F_{1(3)}\end{array}$ & $\begin{array}{l}\text { Availability of accreditation and certifi- } \\
\text { cation }\end{array}$ & Lack of accreditations and certifications \\
\hline $\begin{array}{l}\text { Financing of development pro- } \\
\text { grams, } I F_{1(4)}\end{array}$ & $\begin{array}{l}\text { Available funds for financing develop- } \\
\text { ment programs }\end{array}$ & $\begin{array}{l}\text { Lack of funds to finance development } \\
\text { programs }\end{array}$ \\
\hline \multicolumn{3}{|c|}{ Subsystem "Logistics" $\left(I F_{2}\right)$} \\
\hline Location of the enterprise, $I F_{2(1)}$ & Good placement & Bad location \\
\hline Logistics, $I F_{2(2)}$ & High quality logistics & Bad (poor quality) log \\
\hline Assets and resources, $I F_{2(3)}$ & Adequacy of assets and resources & Lack of assets and res \\
\hline \multicolumn{3}{|c|}{ Subsystem "Production" $\left(I F_{3}\right)$} \\
\hline Technologies and equipment, $I F_{3(1)}$ & Modern technologies and equipment & Outdated technologi \\
\hline $\begin{array}{l}\text { Reserve of production capacities, } \\
I F_{3(2)}\end{array}$ & $\begin{array}{l}\text { Available reserves of production capac- } \\
\text { ity }\end{array}$ & $\begin{array}{l}\text { There is no reserve for production ca- } \\
\text { pacity }\end{array}$ \\
\hline The level of production costs, $I F_{3(3)}$ & Below the industry average & Above the average industry level \\
\hline Ensuring business processes, $I F_{3(4)}$ & High quality organizational support & $\operatorname{Bad}(\mathrm{p}$ \\
\hline \multicolumn{3}{|c|}{ Subsystem "Sales and Promotion" $\left(I F_{4}\right)$} \\
\hline Brand awareness, $I F_{4(1)}$ & $\begin{array}{l}\text { Growing popularity and level of brand } \\
\text { recognition }\end{array}$ & Declining brand popularity \\
\hline Product differentiation, $I F_{4(2)}$ & product differentiation & Narr \\
\hline ict quality, $I F_{4(3)}$ & quality & Low \\
\hline Product sales channels, $I F_{4(4)}$ & Developed sales c & Unde \\
\hline Pricing policy, $I F_{4(5)}$ & Existence of a reasonable pricing policy & Lack \\
\hline \multicolumn{3}{|c|}{ Subsystem "Enterprise Finance” $\left(I F_{5}\right)$} \\
\hline Equit & Sufficient share of equity & Lacl \\
\hline Financial results, $I F_{5(2)}$ & High financial results & Unsa \\
\hline Profitability of brands, $I F_{5(3)}$ & High profitability & of non \\
\hline $\begin{array}{l}\text { Financial liquidity and solvency, } \\
I F_{5(4)}\end{array}$ & $\begin{array}{l}\text { Ability to repay accounts payable in a } \\
\text { timely manner }\end{array}$ & Lack of funds to repay accounts payable \\
\hline Financial stability, $I F_{5(5)}$ & $\begin{array}{l}\text { Ability to finance activities from inter- } \\
\text { nal sources }\end{array}$ & $\begin{array}{l}\text { Unsecured } \\
\text { internal sou }\end{array}$ \\
\hline \multicolumn{3}{|c|}{ Subsystem "Personnel Management" $\left(I F_{6}\right)$} \\
\hline $\begin{array}{l}\text { Provision of management staff, } \\
I F_{6(1)}\end{array}$ & Competence of management staff & Lack of ma \\
\hline $\begin{array}{l}\text { Provision of industrial and produc- } \\
\text { tion personnel, } I F_{6(2)}\end{array}$ & $\begin{array}{l}\text { Provision of industrial and production } \\
\text { personnel }\end{array}$ & $\begin{array}{l}\text { Insecurity of industrial and production } \\
\text { personnel }\end{array}$ \\
\hline $\begin{array}{l}\text { Competence of management staff, } \\
I F_{6(3)}\end{array}$ & High qualification of management staff & Low qualification of management staff \\
\hline $\begin{array}{l}\text { Qualification of engineering and } \\
\text { technical workers, } I F_{6(4)}\end{array}$ & $\begin{array}{l}\text { High qualification of engineering and } \\
\text { technical workers }\end{array}$ & $\begin{array}{l}\text { Low qualification of engineering and } \\
\text { technical workers }\end{array}$ \\
\hline The level of wages, $I F_{6(5)}$ & Above the average industry level & Below the \\
\hline Remuneration mechanisms, $I F_{6(6)}$ & $\begin{array}{l}\text { Increasing the incentive for high quality } \\
\text { work }\end{array}$ & Lack of incentives for quality of work \\
\hline $\begin{array}{l}\text { Opportunities for professional and } \\
\text { career growth } I F_{6(7)}\end{array}$ & $\begin{array}{l}\text { Opportunities for professional and ca- } \\
\text { reer growth }\end{array}$ & $\begin{array}{l}\text { Lack of opportunities for professional } \\
\text { and career growth }\end{array}$ \\
\hline \multicolumn{3}{|c|}{ Subsystem "Strategic and tactical management" $\left(I F_{7}\right)$} \\
\hline $\begin{array}{l}\text { Innovation and creativity of man- } \\
\text { agers, } I F_{7(1)}\end{array}$ & $\begin{array}{l}\text { High level of innovation and creativity } \\
\text { of managers }\end{array}$ & $\begin{array}{l}\text { Low level of innovation and creativity } \\
\text { of managers }\end{array}$ \\
\hline $\begin{array}{l}\text { Strategic management mechanism, } \\
I F_{7(2)}\end{array}$ & $\begin{array}{l}\text { Developed mechanism of strategic man- } \\
\text { agement }\end{array}$ & $\begin{array}{l}\text { Undeveloped mechanism of strategic } \\
\text { management }\end{array}$ \\
\hline Tactical control mechanism, $I F_{7(3)}$ & $\begin{array}{l}\text { Developed mechanism of tactical con- } \\
\text { trol }\end{array}$ & $\begin{array}{l}\text { Undeveloped mechanism of tactical } \\
\text { control }\end{array}$ \\
\hline Corporate culture, $I F_{7(4)}$ & Positive corporate culture & Ineffective corporate culture \\
\hline
\end{tabular}


Table 2. A list of key factors for assessing the degree of environmental impact on the enterprise

\begin{tabular}{|c|c|c|}
\hline The name of the factor $E F_{i(j)}$ & Opportunities, $E F_{i(j)}^{(+)}$ & Threats $E F_{i(j)}^{(-)}$ \\
\hline \multicolumn{3}{|c|}{ Subsystem "Intermediate environment (external environment of direct action)" $\left(E F_{1}\right)$} \\
\hline Competition in the industry, $E F_{1(1)}$ & $\begin{array}{l}\text { Stabilization of competition in the in- } \\
\text { dustry }\end{array}$ & $\begin{array}{l}\text { Exacerbation of competition in the in- } \\
\text { dustry }\end{array}$ \\
\hline $\begin{array}{l}\text { Production capacity in the industry, } \\
E F_{1(2)}\end{array}$ & $\begin{array}{l}\text { Increasing production capacity in the in- } \\
\text { dustry }\end{array}$ & $\begin{array}{l}\text { Reducing production capacity in the in- } \\
\text { dustry }\end{array}$ \\
\hline $\begin{array}{l}\text { Economic contractors and con- } \\
\text { tracts, } E F_{1(3)}\end{array}$ & $\begin{array}{l}\text { Emergence of new contractors and the } \\
\text { possibility of signing important con- } \\
\text { tracts }\end{array}$ & $\begin{array}{l}\text { Loss of new important contracts and } \\
\text { contractors }\end{array}$ \\
\hline $\begin{array}{l}\text { Competition with manufacturers of } \\
\text { substitute products, } E F_{1(4)}\end{array}$ & $\begin{array}{l}\text { Stabilization of competition with pro- } \\
\text { ducers of substitute goods }\end{array}$ & $\begin{array}{l}\text { Exacerbation of competition wi } \\
\text { ducers of substitute products }\end{array}$ \\
\hline New product sales channels, $E F_{1(5)}$ & $\begin{array}{l}\text { The emergence of new available mar- } \\
\text { keting tools to promote products }\end{array}$ & Reduction of existing sales channels \\
\hline $\begin{array}{l}\text { New marketing tools for product } \\
\text { promotion, } E F_{1(6)}\end{array}$ & $\begin{array}{l}\text { The emergence of new available mar- } \\
\text { keting tools to promote products }\end{array}$ & $\begin{array}{l}\text { The eme } \\
\text { keting to }\end{array}$ \\
\hline Market demand, $E F_{1(7)}$ & Rising average industry price & $\begin{array}{l}\text { Reduction of demand in exi } \\
\text { kets }\end{array}$ \\
\hline Price, $E F_{1(8)}$ & & Decrease in the \\
\hline New markets for products, $E F_{1(9)}$ & Emergence of new markets & Loss of existir \\
\hline Staffing, $E F_{1(10)}$ & $\begin{array}{l}\text { Training of a significant number of } \\
\text { qualified personnel }\end{array}$ & $\begin{array}{l}\text { Lack of qualif } \\
\text { market }\end{array}$ \\
\hline $\begin{array}{l}\text { Prices for raw materials and elec- } \\
\text { tricity, } E F_{1(11)}\end{array}$ & $\begin{array}{l}\text { Reduction of prices for raw materials } \\
\text { and electricity }\end{array}$ & $\begin{array}{l}\text { Rising prices for raw } \mathrm{m} \\
\text { tricity }\end{array}$ \\
\hline Terms of external financing, $I F_{1(12)}$ & $\begin{array}{l}\text { tive conditions of external (loan) } \\
\text { ing }\end{array}$ & $\begin{array}{l}\text { Una } \\
\text { of ex }\end{array}$ \\
\hline Product advertising, $E F_{1(13)}$ & $\begin{array}{l}\text { ding opportunities for product ad- } \\
\text { ing }\end{array}$ & $\begin{array}{l}\text { ving opl } \\
\text { ng }\end{array}$ \\
\hline $\begin{array}{l}\text { Transformation of tastes and prefer- } \\
\text { ences of consumers, } E F_{1(14)}\end{array}$ & $\begin{array}{l}\text { Correct assessment of new tastes and } \\
\text { preferences of consumers }\end{array}$ & $\begin{array}{l}\text { Incorrect assessment } \\
\text { preferences of consu }\end{array}$ \\
\hline \multicolumn{3}{|c|}{ Subsystem "Macro environment (external environment of indirect action)" $\left(I F_{2}\right)$} \\
\hline Political situation, $E F_{2(1)}$ & $\begin{array}{l}\text { Improving the military-political situa- } \\
\text { tion }\end{array}$ & $\begin{array}{l}\text { Exacerbation of the mili } \\
\text { situation }\end{array}$ \\
\hline Legislation, $E F_{2(2)}$ & $\begin{array}{l}\text { Stability, completeness and internal } \\
\text { consistency of the legal framework }\end{array}$ & $\begin{array}{l}\text { Instability, incompleten } \\
\text { contradictions of the leg }\end{array}$ \\
\hline $\begin{array}{l}\text { New production / technologies, } \\
E F_{2(3)}\end{array}$ & $\begin{array}{l}\text { Emergence of new available types of } \\
\text { equipment / production technology }\end{array}$ & $\begin{array}{l}\text { Emergence of new inaccessible types of } \\
\text { equipment / technologies of production }\end{array}$ \\
\hline $\begin{array}{l}\text { New information technologies, } \\
E F_{2(4)}\end{array}$ & $\begin{array}{l}\text { Emergence of new available informa- } \\
\text { tion technologies }\end{array}$ & $\begin{array}{l}\text { The emergence of new inaccessible in- } \\
\text { formation technology }\end{array}$ \\
\hline Training and retraining, $E F_{2(5)}$ & $\begin{array}{l}\text { Extensive opportunities for training and } \\
\text { retraining }\end{array}$ & $\begin{array}{l}\text { Reduction of bases for training and re- } \\
\text { training }\end{array}$ \\
\hline Raw material base, $E F_{2(6)}$ & $\begin{array}{l}\text { Development of the national raw mate- } \\
\text { rial base }\end{array}$ & Dependence on imported suppliers of \\
\hline Intellectual Property, $E F_{2(7)}$ & $\begin{array}{l}\text { Development of services for the protec- } \\
\text { tion of intellectual property }\end{array}$ & $\begin{array}{l}\text { Lack of intellectual property protection } \\
\text { services }\end{array}$ \\
\hline & nproving climatic conditions & Deterioration of climat \\
\hline Welfare of the population, $E F_{2(9)}$ & Improving the welfare of the population & $\begin{array}{l}\text { Deterioration of the welfare of the pop- } \\
\text { ulation }\end{array}$ \\
\hline $\mathrm{s}, E F_{2(10)}$ & & \\
\hline & ase in excise duty & Reduction of excise \\
\hline Pandemic, $E F_{2(12)}$ & Improving the pandemic situation & Deterioration of the pandemic situation \\
\hline
\end{tabular}


Table 3. Matrix of pairwise comparisons for estimation of weighting factors on internal factors of the subsystem "Innovation and development" $\left(F_{1}\right)$

\begin{tabular}{lllll}
\hline Subsystem & $I F_{1(1)}$ & $I F_{1(2)}$ & $I F_{1(3)}$ & $I F_{1(4)}$ \\
\hline $\begin{array}{l}\text { Experience in de- } \\
\text { veloping new prod- }\end{array}$ & $E I$ & $S A^{-1}$ & $B A$ & $E I$ \\
ucts and brands, & & & & \\
$I F_{1(1)}$ & & & & \\
$\begin{array}{l}\text { Reputation and im- } \\
\text { age of the com- }\end{array}$ & $S A$ & $E I$ & $S A$ & $S A$ \\
$\begin{array}{l}\text { pany, } I F_{1(2)} \\
\text { Accreditation and } \\
\text { certification, } I F_{1(3)}\end{array}$ & $B A^{-1}$ & $S A^{-1}$ & $E I$ & $S A^{-1}$ \\
$\begin{array}{l}\text { Financing of } \\
\text { development } \\
\text { programs } I F_{1(4)}\end{array}$ & $E I$ & $S A^{-1}$ & SA & $E I$ \\
Weight values & 0.256 & 0.389 & 0.124 & 0.231 \\
\hline
\end{tabular}

Table 4. Calculation of weights by groups of environmental factors $(\mathrm{EF})$

\begin{tabular}{llll}
\hline Subsystem & & $E F_{(1)}$ & $E F_{(2)}$ \\
\hline Intermediate environment & $E F_{(1)}$ & $E I$ & $S A$ \\
Macroenvironment & $E F_{(2)}$ & $S A^{-1}$ & $E I$ \\
Weight values & 1.00 & 0.666 & 0.334 \\
\hline
\end{tabular}

Neutral factors are important in terms of their changes in dynamics and require constant monitoring of their deviations.

The use of 3, 5 or 7 level scales, which are always the most convenient for the expert, will determine the degree of deviation from the norm in a positive or negative direction. Experts will be able to use different types of scales - current, interval and fuzzy research scales. An important condition is compliance with a single scale in terms of expert evaluation. Weight values within a given hierarchy of indicators can be determined on the basis of Fishburne's rule or the method of pairwise comparisons by Saati. It should be noted that for a qualitative interpretation of strengths and weaknesses, for example, on a 5-level scale, it will be necessary to list in a given proportion the weight values of a particular group up to $100 \%$. If this is not done, the proportion may be different and the results will not be subject to a 5-level study scale. And to assess the balance between strengths and weaknesses, it will be necessary to list in a given proportion of weight values by factors of strengths and weaknesses (excluding the action of neutral factors), so that their share was $100 \%$.

\section{Discussion of research results}

\subsection{Key influencing factors for public partnership "Carlsberg Ukraine"}

The implementation of the proposed approach to SWOT analysis will be carried out for public partnership "Carlsberg Ukraine" - one of the largest players in brewing in Ukraine in 2020. The study was conducted on the basis of reporting information of the enterprise and information from external sources, in particular [19].
Systematization and generalization of information on the internal and external environment allowed to identify a list of key factors of influence. The strengths of public partnership "Carlsberg Ukraine" include the following factors $\left(I F^{(+)}\right)$:

- $I F_{1(1)}^{(+)}$- extensive experience in developing new products and brands;

- $I F_{1(2)}^{(+)}$- good reputation and image;

- $I F_{2(2)}^{(+)}-$logistics;

- $I F_{3(2)}^{(+)}$- significant scale of production and available reserves of production capacity;

- $I F_{4(1)}^{(+)}$- increasing the popularity and recognition of brands;

- $I F_{4(2)}^{(+)}$- wide product differentiation;

- $I F_{4(3)}^{(+)}-$high quality products;

- $I F_{4(4)}^{(+)}$- developed product sales channels (retail chains, individual outlets, restaurants, cafes, pubs);

- $I F_{4(5)}^{(+)}$- the existence of a reasonable pricing policy (law mainstream, mainstream, premium, super premium);

- $I F_{5(2)}^{(+)}$- financial results;

- $I F_{6(2)}^{(+)}$- provision of industrial and production personnel;

- $I F_{6(5)}^{(+)}$- the level of wages corresponds to the average industry level;

- $I F_{6(7)}^{(+)}$- opportunity for professional and career growth;

- $I F_{7(4)}^{(+)}$- positive corporate culture.

And the weaknesses of public partnership "Carlsberg Ukraine" are the following factors $\left(I F^{(-)}\right)$:

- $I F_{1(4)}^{(-)}$- insufficient funding for development programs;

- $I F_{2(3)}^{(-)}-$lack of assets and resources;

- $I F_{3(1)}^{(-)}$- availability of outdated technologies and equipment;

- $I F_{3(3)}^{(-)}$- the level of production costs is higher than the industry average;

- $I F_{5(1)}^{(-)}-$lack of equity;

- $I F_{5(3)}^{(-)}$- the presence of non-profit brands;

- $I F_{5(4)}^{(-)}-$lack of funds to repay accounts payable;

- $I F_{5(5)}^{(-)}$- unsecured financing of activities from internal sources;

- $I F_{6(1)}^{(-)}$- staff turnover and insecurity of management staff;

- $I F_{6(3)}^{(-)}$- competence of management staff;

- $I F_{6(7)}^{(-)}$- lack of proper incentives for quality of work;

- $I F_{7(1)}^{(-)}$- insufficient level of innovation and creativity;

- $I F_{7(2)}^{(-)}$- an underdeveloped strategic management mechanism. 
Table 5. Calculation of weights by groups of factors of the internal environment (IF)

\begin{tabular}{|c|c|c|c|c|c|c|c|c|}
\hline Subsystem & & $I F_{1}$ & $I F_{2}$ & $I F_{3}$ & $I F_{4}$ & $I F_{5}$ & $I F_{6}$ & $I F_{7}$ \\
\hline Innovation and development & $I F_{1}$ & $E I$ & $S A$ & $S A$ & $S A$ & $S A^{-1}$ & $S A^{-1}$ & $E I$ \\
\hline Logistics & $I F_{2}$ & $S A^{-1}$ & $E I$ & $B A$ & $S A^{-1}$ & $S A^{-1}$ & $B A^{-1}$ & $S A^{-1}$ \\
\hline Production & $I F_{3}$ & $S A^{-1}$ & $B A^{-1}$ & $E I$ & $S A$ & $S A$ & $S A^{-1}$ & $S A^{-1}$ \\
\hline Sales and product promotion & $I F_{4}$ & $S A^{-1}$ & $S A$ & $S A^{-1}$ & $E I$ & $S A^{-1}$ & $B A^{-1}$ & $E I$ \\
\hline Enterprise finances & $I F_{5}$ & $S A$ & $S A$ & $S A^{-1}$ & $S A$ & $E I$ & $S A$ & $S A^{-1}$ \\
\hline$H R$ & $I F_{6}$ & $S A$ & $B A$ & $S A$ & $B A$ & $S A^{-1}$ & EI & $S A^{-1}$ \\
\hline Strategic and tactical management & $I F_{7}$ & $E I$ & $S A$ & $S A$ & $E I$ & $S A$ & $S A$ & $E I$ \\
\hline Weighting factor & 1.00 & 0.151 & 0.092 & 0.106 & 0.096 & 0.166 & 0.187 & 0.203 \\
\hline
\end{tabular}

Table 6. The results of the evaluation of the weights of the internal environment

\begin{tabular}{|c|c|c|}
\hline Factor / subsystem & $\begin{array}{l}\text { Weight within sub- } \\
\text { systems }\end{array}$ & $\begin{array}{l}\text { Normalized weight } \\
\text { values within the } \\
\text { system }\end{array}$ \\
\hline \multicolumn{3}{|c|}{ Subsystem "Innovation and Development" $\left(I F_{1}\right)$} \\
\hline Experience in developing new products, $I F_{1(1)}$ & 0.256 & 0.039 \\
\hline Reputation and image of the company, $I F_{1(2)}$ & 0.389 & 0.059 \\
\hline Accreditation and certification, $I F_{1(3)}$ & 0.124 & 0.019 \\
\hline Financing of development programs, $I F_{1(4)}$ & 0.231 & 0.035 \\
\hline \multicolumn{3}{|c|}{ Subsystem “Logistics" $\left(I F_{2}\right)$} \\
\hline Location of the enterprise, $I F_{2(1)}$ & 0.260 & 0.024 \\
\hline Logistics, $I F_{2(2)}$ & 0.327 & 0.030 \\
\hline Assets and resources, $I F_{2(3)}$ & 0.413 & 0.038 \\
\hline \multicolumn{3}{|c|}{ Subsystem "Production" $\left(I F_{3}\right)$} \\
\hline Technologies and equipment, $I F_{3(1)}$ & 0.238 & 0.025 \\
\hline Reserve of production capacities, $I F_{3(2)}$ & 0.142 & 0.015 \\
\hline The level of production costs, $I F_{3(3)}$ & 0.337 & 0.036 \\
\hline Ensuring business processes, $I F_{3(4)}$ & 0.283 & 0.030 \\
\hline \multicolumn{3}{|c|}{ Subsystem "Sales and Promotion" $\left(I F_{4}\right)$} \\
\hline Brand awareness, $I F_{4(1)}$ & 0.134 & 0.013 \\
\hline Product differentiation, $I F_{4(2)}$ & 0.167 & 0.016 \\
\hline Product quality, $I F_{4(3)}$ & 0.192 & 0.018 \\
\hline Product sales channels, $I F_{4(4)}$ & 0.192 & 0.018 \\
\hline Pricing policy, $I F_{4(5)}$ & 0.315 & 0.030 \\
\hline \multicolumn{3}{|c|}{ Subsystem "Enterprise Finance" $\left(I F_{5}\right)$} \\
\hline Equity, $I F_{5(1)}$ & 0.254 & 0.042 \\
\hline Financial results, $I F_{5(2)}$ & 0.124 & 0.021 \\
\hline Profitability of brands, $I F_{5(3)}$ & 0.164 & 0.027 \\
\hline Financial liquidity and solvency, $I F_{5(4)}$ & 0.094 & 0.016 \\
\hline Financial stability, $I F_{5(5)}$ & 0.364 & 0.061 \\
\hline \multicolumn{3}{|c|}{ Subsystem "Personnel Management" $\left(I F_{6}\right)$} \\
\hline Provision of management staff, $I F_{6(1)}$ & 0.140 & 0.026 \\
\hline Provision of industrial and production personnel, $I F_{6(2)}$ & 0.100 & 0.019 \\
\hline Competence of management staff, $I F_{6(3)}$ & 0.192 & 0.036 \\
\hline Qualification of engineering and technical workers, $I F_{6(4)}$ & 0.077 & 0.014 \\
\hline The level of wages, $I F_{6(5)}$ & 0.104 & 0.019 \\
\hline Remuneration mechanisms, $I F_{6(6)}$ & 0.212 & 0.040 \\
\hline Opportunities for professional and career growth, $I F_{6(7)}$ & 0.174 & 0.032 \\
\hline \multicolumn{3}{|c|}{ Subsystem "Strategic and tactical management" $\left(I F_{7}\right)$} \\
\hline Innovation and creativity of managers, $I F_{7(1)}$ & 0.161 & 0.033 \\
\hline Strategic management mechanism, $I F_{7(2)}$ & 0.270 & 0.055 \\
\hline Tactical control mechanism, $I F_{7(3)}$ & 0.299 & 0.061 \\
\hline Corporate culture, $I F_{7(4)}$ & 0.270 & 0.055 \\
\hline Total by groups & & 1 \\
\hline
\end{tabular}


Table 7. The results of the assessment of the weights of the environment

\begin{tabular}{|c|c|c|}
\hline Factor / subsystem & $\begin{array}{l}\text { Weight within } \\
\text { subsystems }\end{array}$ & $\begin{array}{l}\text { Normalized } \\
\text { weight values } \\
\text { within the system }\end{array}$ \\
\hline \multicolumn{3}{|c|}{ Subsystem "Intermediate environment (external environment of direct action)" $\left(E F_{1}\right)$} \\
\hline Competition in the industry, $E F_{1(1)}$ & 0.090 & 0.060 \\
\hline Production capacity in the industry, $E F_{1(2)}$ & 0.090 & 0.060 \\
\hline Economic contractors and contracts, $E F_{1(3)}$ & 0.095 & 0.063 \\
\hline Competition with manufacturers of substitute products, $E F_{1(4)}$ & 0.079 & 0.053 \\
\hline New product sales channels, $E F_{1(5)}$ & 0.067 & 0.045 \\
\hline New marketing tools for product promotion, $E F_{1(6)}$ & 0.074 & 0.049 \\
\hline Market demand, $E F_{1(7)}$ & 0.057 & 0.038 \\
\hline Price, $E F_{1(8)}$ & 0.066 & 0.044 \\
\hline New markets for products, $E F_{1(9)}$ & 0.102 & 0.068 \\
\hline Staffing, $E F_{1(10)}$ & 0.050 & 0.033 \\
\hline Prices for raw materials and electricity, $E F_{1(11)}$ & 0.086 & 0.058 \\
\hline Terms of external financing, $E F_{1(12)}$ & 0.032 & 0.022 \\
\hline Product advertising, $E F_{1(13)}$ & 0.046 & 0.030 \\
\hline Transformation of tastes and preferences of consumers, $E F_{1(14)}$ & 0.065 & 0.043 \\
\hline \multicolumn{3}{|c|}{ Subsystem "Macro environment (external environment of indirect action)" $\left(E F_{2}\right)$} \\
\hline Political situation, $E F_{2(1)}$ & 0.087 & 0.029 \\
\hline Legislation, $E F_{2(2)}$ & 0.100 & 0.033 \\
\hline New production / technologies, $E F_{2(3)}$ & 0.087 & 0.029 \\
\hline New information technologies, $E F_{2(4)}$ & 0.060 & 0.020 \\
\hline Training and retraining, $E F_{2(5)}$ & 0.077 & 0.026 \\
\hline Raw material base, $E F_{2(6)}$ & 0.061 & 0.020 \\
\hline Intellectual Property, $E F_{2(7)}$ & 0.058 & 0.019 \\
\hline Weather, $E F_{2(8)}$ & 0.066 & 0.022 \\
\hline Welfare of the population, $E F_{2(9)}$ & 0.095 & 0.032 \\
\hline Export quotas, $E F_{2(10)}$ & 0.110 & 0.037 \\
\hline Excise duty, $E F_{2(11)}$ & 0.095 & 0.032 \\
\hline Pandemic, $E F_{2(12)}$ & 0.104 & 0.035 \\
\hline Total by groups & - & 1 \\
\hline
\end{tabular}

Neutral factors of the internal environment included such factors of influence as: location of the enterprise $\left(I F_{2(1)}\right)$; accreditation and certification $\left(I F_{1(3)}\right)$; business process support $\left(I F_{3(4)}\right)$; qualification of engineering and technical staff $\left(I F_{6(4)}\right)$ and tactical management mecha$\operatorname{nism}\left(I F_{7(3)}\right)$.

Let's identify possible threats for public partnership "Carlsberg Ukraine" $\left(E F^{(-)}\right)$:

- $E F_{1(1)}^{(-)}$- intensification of competition in the industry;

- $E F_{1(2)}^{(-)}$- increase production capacity in the industry;

- $E F_{1(4)}^{(-)}$- intensification of competition with producers of substitute products (spirits);

- $E F_{1(7)}^{(-)}-$reduction of demand in available markets;

- $E F_{1(11)}^{(-)}$- reduction of demand in available markets;

- $E F_{1(13)}^{(-)}$- narrowing of opportunities for product advertising (ban on outdoor advertising of soft drinks);

- $E F_{1(14)}^{(-)}$- incorrect assessment of new tastes and preferences of consumers;

- $E F_{2(1)}^{(-)}$- aggravation of the military-political situation (war in the East of the country and annexation of Crimea);
- $E F_{2(2)}^{(-)}$- instability, incompleteness and internal contradiction of the legal framework;

- $E F_{2(3)}^{(-)}$- emergence of new inaccessible types of machinery / technologies of production;

- $E F_{2(6)}^{(-)}$- underdeveloped national raw material base and dependence on imported suppliers of raw materials (barley, malt, cork, etc);

- $E F_{2(8)}^{(-)}$-deterioration of climatic conditions;

- $E F_{2(9)}^{(-)}$-deterioration of the welfare of the population;

- $E F_{2(11)}^{(-)}-$increase in excise duty on beer;

- $E F_{2(12)}^{(-)}$-deterioration of the pandemic situation.

Let's define the main opportunities for public partnership "Carlsberg Ukraine" $\left(E F^{(+)}\right)$:

- $E F_{1(3)}^{(+)}$- the emergence of new contractors and the possibility of signing important contracts;

- $E F_{1(5)}^{(+)}$- the emergence of new sales channels;

- $E F_{1(6)}^{(+)}$- the emergence of new available marketing tools to promote products;

- $E F_{1(8)}^{(+)}$- growth of the average industry price; 
- $E F_{1(9)}^{(+)}$- the emergence of new markets;

- $E F_{1(10)}^{(+)}$- training of a significant number of qualified personnel;

- $E F_{1(12)}^{(+)}$- attractive external financing conditions;

- $E F_{2(5)}^{(+)}$- wide opportunities for training and advanced training;

- $E F_{2(7)}^{(+)}$- development of intellectual property protection services.

Neutral environmental factors included information factors such as: information technology $\left(E F_{2(4)}\right)$ and export quotas $\left(E F_{2(10)}\right)$.

The level of influence of factors of positive / negative action on the functioning of the enterprise will be assessed using a five-level scale. We have identified such levels of influence as: "1" - very insignificant, "2" - insignificant, "3" - moderate, "4" - significant and " 5 " - very significant.

In order to assess the performance of strengths / weaknesses on a 5-level scale, we recalculated the weights of factors up to $100 \%$ and conducted a qualitative assessment.

\subsection{Analysis of strengths and weaknesses of public partnership "Carlsberg Ukraine"}

Analysis of strengths and weaknesses of public partnership "Carlsberg Ukraine" are shown in tables 8 and 9.

The results of the calculation allow us to state that the influence of strengths $\left(I F^{(+)}=3.043\right)$ on the internal subsystem of public partnership "Carlsberg Ukraine" is medium (moderate), and the influence of weaknesses( $\left.I F^{(-)}=1.814\right)-$ insignificant.

As noted above, to assess the balance between strengths and weaknesses, recalculation was performed in a given proportion of weight values by factors of strengths and weaknesses (excluding the action of neutral factors), (equations 3, 4): $I F^{(+)}=1.371 ; I F^{(-)}=0.997$.

Since a single scale is used to analyse the influence of internal environmental factors, the balance between the action of strengths and weaknesses will be determined by equation (10), the result is: $I F=1.371-0.997=0.374$.

The obtained indicator shows that the strengths of public partnership "Carlsberg Ukraine" outweigh its weaknesses by +0.374 . The company has its own capacity, financial resources, experience and capabilities in developing new brands, developed product promotion channels, flexible pricing policy and wide product differentiation. Weaknesses of the enterprise that weaken the balance include outdated technologies and non-profit brands, insufficient funding for development projects, indicators of financial stability.

\subsection{Analysis of the impact of external opportunities and threats for public partnership "Carlsberg Ukraine"}

Next, an analysis of the impact of external opportunities and threats to public partnership "Carlsberg Ukraine". The results of the analysis are shown in tables 10 and 11 .
Table 8. The results of the assessment of the strengths of public partnership "Carlsberg Ukraine" on a 5-level scale for 2020

\begin{tabular}{|c|c|c|c|c|}
\hline Factor & $\begin{array}{l}\text { The } \\
\text { weight } \\
\text { of the } \\
\text { factor } \\
\text { in a } \\
\text { single } \\
\text { scale }\end{array}$ & $\begin{array}{l}\text { The } \\
\text { weight } \\
\text { of the } \\
\text { factor } \\
\text { in as- } \\
\text { sessing } \\
\text { strengths }\end{array}$ & $\begin{array}{l}\text { Factor } \\
\text { im- } \\
\text { pact } \\
\text { as- } \\
\text { sess- } \\
\text { ment }\end{array}$ & $\begin{array}{l}\text { Weighted } \\
\text { assess- } \\
\text { ment }\end{array}$ \\
\hline $\begin{array}{lr}\text { Experience } & \text { in } \\
\text { developing } & \text { new } \\
\text { products } & \text { and } \\
\text { brands, } I F_{1(1)}\end{array}$ & 0.039 & 0.100 & 4.000 & 0.402 \\
\hline $\begin{array}{l}\text { Reputation and } \\
\text { image of the } \\
\text { company, } I F_{1(2)}\end{array}$ & 0.059 & 0.153 & 3.000 & 0.458 \\
\hline Logistics, $I F_{2(2)}$ & 0.030 & 0.078 & 2.000 & 0.157 \\
\hline $\begin{array}{l}\text { Reserve of } \\
\text { production ca- } \\
\text { pacities, } I F_{3(2)}\end{array}$ & 0.015 & 0.039 & 3.000 & 0.117 \\
\hline $\begin{array}{l}\text { Brand recogni- } \\
\text { tion, } I F_{4(1)}\end{array}$ & 0.013 & 0.033 & 4.000 & 0.134 \\
\hline $\begin{array}{l}\text { Product differen- } \\
\text { tiation, } I F_{4(2)}\end{array}$ & 0.016 & 0.042 & 4.000 & 0.166 \\
\hline $\begin{array}{l}\text { Product quality, } \\
I F_{4(3)}\end{array}$ & 0.018 & 0.048 & 3.000 & 0.143 \\
\hline $\begin{array}{l}\text { Product sales } \\
\text { channels, } I F_{4(4)}\end{array}$ & 0.018 & 0.048 & 3.000 & 0.143 \\
\hline $\begin{array}{l}\text { Pricing policy, } \\
I F_{4(5)}\end{array}$ & 0.030 & 0.079 & 4.000 & 0.314 \\
\hline $\begin{array}{l}\text { Financial results, } \\
I F_{5(2)}\end{array}$ & 0.021 & 0.054 & 2.000 & 0.108 \\
\hline $\begin{array}{l}\text { Provision of } \\
\text { industrial and } \\
\text { production per- } \\
\text { sonnel, } I F_{6(2)}\end{array}$ & 0.019 & 0.049 & 4.000 & 0.195 \\
\hline $\begin{array}{l}\text { The level of } \\
\text { wages, } I F_{6(5)}\end{array}$ & 0.019 & 0.051 & 1.000 & 0.051 \\
\hline $\begin{array}{l}\text { Career opportuni- } \\
\text { ties, } I F_{6(7)}\end{array}$ & 0.032 & 0.085 & 1.000 & 0.085 \\
\hline $\begin{array}{l}\text { Corporate cul- } \\
\text { ture, } I F_{7(4)}\end{array}$ & 0.055 & 0.143 & 4.000 & 0.571 \\
\hline Total & 0.384 & 1.000 & - & 3.043 \\
\hline
\end{tabular}

These calculations allow us to state that the impact of external threats $\left(E F^{(-)}=2.338\right)$ on the activities of public partnership "Carlsberg Ukraine" is moderate. and external opportunities $\left(E F^{(+)}=2.941\right)$ can be interpreted as moderate (average).

Similar to the calculation of the balance between strengths and weaknesses. Let's calculate the balance between external opportunities and threats to the environment (equations 8, 9): $E F^{(+)}=1.150 ; E F^{(-)}=1.423$.

To analyze the balance between the action of external opportunities and threats. We use the equation (11): $E F=$ $1.150-1.423=-0.273$.

The obtained negative value indicates that the balance is shifted towards the threats of the enterprise. and proves 
Table 9. The results of the assessment of the weaknesses of public partnership "Carlsberg Ukraine" on a 5-level scale for 2020

\begin{tabular}{|c|c|c|c|c|}
\hline Factor & $\begin{array}{l}\text { The } \\
\text { weight } \\
\text { of the } \\
\text { factor } \\
\text { in a } \\
\text { single } \\
\text { scale }\end{array}$ & $\begin{array}{l}\text { The } \\
\text { weight } \\
\text { of the } \\
\text { factor } \\
\text { in as- } \\
\text { sessing } \\
\text { strengths }\end{array}$ & $\begin{array}{l}\text { Factor } \\
\text { im- } \\
\text { pact } \\
\text { as- } \\
\text { sess- } \\
\text { ment }\end{array}$ & $\begin{array}{l}\text { Weighted } \\
\text { assess- } \\
\text { ment }\end{array}$ \\
\hline $\begin{array}{l}\text { Financing of } \\
\text { development } \\
\text { programs, } I F_{1(4)}\end{array}$ & 0.035 & 0.074 & 2.000 & 0.149 \\
\hline $\begin{array}{l}\text { Assets and } \\
\text { resources, } I F_{2(3)}\end{array}$ & 0.038 & 0.081 & 1.000 & 0.081 \\
\hline $\begin{array}{l}\text { Technologies and } \\
\text { equipment, } I F_{3(1)}\end{array}$ & 0.025 & 0.054 & 2.000 & 0.107 \\
\hline $\begin{array}{l}\text { The level of } \\
\text { production costs, } \\
I F_{3(3)}\end{array}$ & 0.036 & 0.076 & 1.000 & 0.076 \\
\hline Equity, $I F_{5(1)}$ & 0.042 & 0.090 & 1.000 & 0.090 \\
\hline $\begin{array}{l}\text { Profitability of } \\
\text { brands, } I F_{5(3)}\end{array}$ & 0.027 & 0.058 & 2.000 & 0.115 \\
\hline $\begin{array}{l}\text { Financial liquid- } \\
\text { ity and solvency, } \\
I F_{5(4)}\end{array}$ & 0.016 & 0.034 & 2.000 & 0.068 \\
\hline $\begin{array}{l}\text { Financial stabil- } \\
\text { ity, } I F_{5(5)}\end{array}$ & 0.061 & 0.130 & 3.000 & 0.391 \\
\hline $\begin{array}{l}\text { Provision of } \\
\text { management } \\
\text { staff, } I F_{6(1)}\end{array}$ & 0.026 & 0.055 & 2.000 & 0.111 \\
\hline $\begin{array}{l}\text { Competence of } \\
\text { management } \\
\text { staff, } I F_{6(3)}\end{array}$ & 0.036 & 0.077 & 2.000 & 0.153 \\
\hline $\begin{array}{l}\text { Remuneration } \\
\text { mechanisms, } \\
I F_{6(6)}\end{array}$ & 0.040 & 0.085 & 2.000 & 0.169 \\
\hline $\begin{array}{l}\text { Innovation and } \\
\text { creativity } \\
\text { managers, } I F_{7(1)}\end{array}$ & 0.033 & 0.070 & 1.000 & 0.070 \\
\hline $\begin{array}{l}\text { Strategic man- } \\
\text { agement mecha- } \\
\text { nism, } I F_{7(2)}\end{array}$ & 0.055 & 0.117 & 2.000 & 0.234 \\
\hline Total & 0.468 & 1.000 & - & 1.814 \\
\hline
\end{tabular}

the need for constant monitoring of changes in the action of environmental factors.

\subsection{SPACE matrix for public partnership "Carlsberg Ukraine"}

The SPACE matrix was built based on the values of the balance between strengths and weaknesses, and the balance between opportunities and threats. Thus, based on two values of strategic dimensions EF and IF, we divided the space into four types of strategies: aggressive; conservative; protective or competitive.

For proposed research scale the following combinations are possible:
Table 10. The results of the assessment of the main external opportunities for public partnership "Carlsberg Ukraine"

\begin{tabular}{|c|c|c|c|c|}
\hline Factor & $\begin{array}{l}\text { The } \\
\text { weight } \\
\text { of the } \\
\text { factor } \\
\text { in a } \\
\text { single } \\
\text { scale }\end{array}$ & $\begin{array}{l}\text { The } \\
\text { weight } \\
\text { of the } \\
\text { factor } \\
\text { in as- } \\
\text { sessing } \\
\text { strengths }\end{array}$ & $\begin{array}{l}\text { Factor } \\
\text { im- } \\
\text { pact } \\
\text { as- } \\
\text { sess- } \\
\text { ment }\end{array}$ & $\begin{array}{l}\text { Weighted } \\
\text { assess- } \\
\text { ment }\end{array}$ \\
\hline $\begin{array}{l}\text { Economic } \quad \begin{array}{l}\text { con- } \\
\text { tractors }\end{array} \text { and } \\
\text { contracts, } E F_{1(3)}\end{array}$ & 0.063 & 0.171 & 3.000 & 0.513 \\
\hline $\begin{array}{l}\text { New product } \\
\text { sales } \\
E F_{1(5)}\end{array}$ & 0.045 & 0.121 & 3.000 & 0.363 \\
\hline $\begin{array}{l}\text { New marketing } \\
\text { tools for prod- } \\
\text { uct promotion, } \\
E F_{1(6)}\end{array}$ & 0.049 & 0.134 & 2.000 & 0.267 \\
\hline Price, $E F_{1(8)}$ & 0.044 & 0.120 & 2.000 & 0.240 \\
\hline $\begin{array}{l}\text { New markets for } \\
\text { products, } E F_{1(9)}\end{array}$ & 0.068 & 0.184 & 4.000 & 0.737 \\
\hline $\mathrm{HR}, E F_{1(10)}$ & 0.033 & 0.090 & 3.000 & 0.271 \\
\hline $\begin{array}{l}\text { Terms of external } \\
\text { financing, } E F_{1(12)}\end{array}$ & 0.022 & 0.059 & 2.000 & 0.117 \\
\hline $\begin{array}{l}\text { Training and re- } \\
\text { training, } E F_{2(5)}\end{array}$ & 0.026 & 0.069 & 4.000 & 0.278 \\
\hline $\begin{array}{l}\text { Intellectual Prop- } \\
\text { erty, } E F_{2(7)}\end{array}$ & 0.019 & 0.052 & 3.000 & 0.155 \\
\hline Total & 0.369 & 1.000 & - & 2.941 \\
\hline
\end{tabular}

if $E F>0$ and $I F<0$ we choose a conservative strategy; if $E F \geq 0$ and $I F \geq 0$ we choose the offensive strategy; if $E F<0$ and $I F<0$ we choose the defence strategy; if $E F<0$ and $I F>0$ then choose a competitive strategy.

Thus, according to the SPACE matrix public partnership "Carlsberg Ukraine" is characterised by a competitive strategy (figure 1).

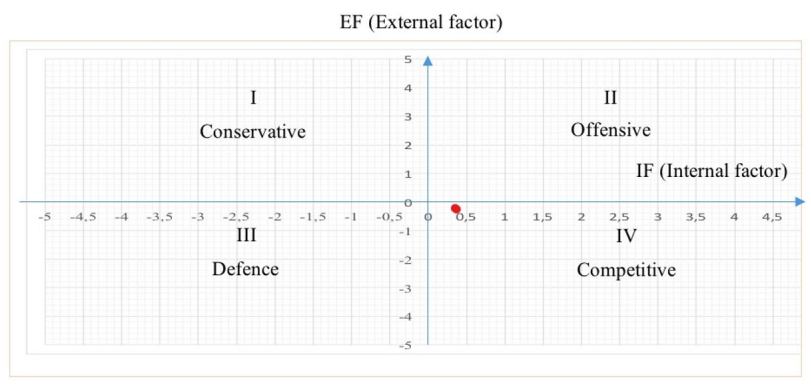

Figure 1. SPACE strategy selection matrix for public partnership "Carlsberg Ukraine"

Filling the four quadrants at the intersection of strengths / weaknesses, opportunities / threats will identify and describe four types of potential strategies for public partnership "Carlsberg Ukraine". In particular, we define:

- potential strategic advantages of the company $(S T)$; 
Table 11. The results of the assessment of the impact of external threats on the activities of public partnership "Carlsberg Ukraine"

\begin{tabular}{|c|c|c|c|c|}
\hline Factor & $\begin{array}{l}\text { The } \\
\text { weight } \\
\text { of the } \\
\text { factor } \\
\text { in a } \\
\text { single } \\
\text { scale }\end{array}$ & $\begin{array}{l}\text { The } \\
\text { weight } \\
\text { of the } \\
\text { factor } \\
\text { in as- } \\
\text { sessing } \\
\text { strengths }\end{array}$ & $\begin{array}{l}\text { Factor } \\
\text { im- } \\
\text { pact } \\
\text { as- } \\
\text { sess- } \\
\text { ment }\end{array}$ & $\begin{array}{l}\text { Weighted } \\
\text { assess- } \\
\text { ment }\end{array}$ \\
\hline $\begin{array}{l}\text { Competition in } \\
\text { the industry, } \\
E F_{1(1)}\end{array}$ & 0.060 & 0.105 & 3.000 & 0.314 \\
\hline $\begin{array}{l}\text { Production ca- } \\
\text { pacity in the } \\
\text { industry, } E F_{1(2)}\end{array}$ & 0.060 & 0.105 & 1.000 & 0.105 \\
\hline $\begin{array}{l}\text { Competition with } \\
\text { manufacturers } \\
\text { of substitute } \\
\text { products, } E F_{1(4)}\end{array}$ & 0.053 & 0.092 & 3.000 & 0.276 \\
\hline $\begin{array}{l}\text { Market demand, } \\
E F_{1(7)}\end{array}$ & 0.038 & 0.066 & 2.000 & 0.133 \\
\hline $\begin{array}{l}\text { Prices for raw } \\
\text { materials and } \\
\text { electricity, } \\
E F_{1(11)}\end{array}$ & 0.058 & 0.100 & 4.000 & 0.401 \\
\hline $\begin{array}{l}\text { Product advertis- } \\
\text { ing, } E F_{1(13)}\end{array}$ & 0.030 & 0.053 & 2.000 & 0.106 \\
\hline $\begin{array}{l}\text { Transformation } \\
\text { of tastes and } \\
\text { preferences }\end{array}$ & 0.043 & 0.076 & 2.000 & 0.151 \\
\hline $\begin{array}{l}\text { of consumers, } \\
E F_{1(14)}\end{array}$ & & & & \\
\hline $\begin{array}{l}\text { Political situa- } \\
\text { tion, } E F_{2(1)}\end{array}$ & 0.029 & 0.051 & 2.000 & 0.101 \\
\hline $\begin{array}{l}\text { Legislation, } \\
E F_{2(2)}\end{array}$ & 0.033 & 0.058 & 1.000 & 0.058 \\
\hline $\begin{array}{l}\text { New production } \\
/ \text { technologies, } \\
E F_{2(3)}\end{array}$ & 0.029 & 0.050 & 2.000 & 0.101 \\
\hline $\begin{array}{l}\text { Raw material } \\
\text { base, } E F_{2(6)}\end{array}$ & 0.020 & 0.035 & 2.000 & 0.071 \\
\hline Weather, $E F_{2(8)}$ & 0.022 & 0.038 & 3.000 & 0.115 \\
\hline $\begin{array}{l}\text { Welfare of the } \\
\text { population, } \\
E F_{2(9)}\end{array}$ & 0.032 & 0.055 & 2.000 & 0.110 \\
\hline $\begin{array}{l}\text { Excise duty, } \\
E F_{2(11)}\end{array}$ & 0.032 & 0.055 & 1.000 & 0.055 \\
\hline $\begin{array}{l}\text { Pandemic, } \\
E F_{2(12)}\end{array}$ & 0.035 & 0.060 & 4.000 & 0.241 \\
\hline Total & 0.574 & 1.000 & - & 2.338 \\
\hline
\end{tabular}

- guidelines for strategic development of the company $(\mathrm{SO})$

- limitation of strategic development (WT);

- landmarks of internal transformations of the enterprise $(W O)$.

At the intersection of strengths and opportunities we substantiate the guidelines for strategic development for public partnership "Carlsberg Ukraine" (table 12).

The analysis of behavioral strategies of Public partnership "Carlsberg Ukraine" is aimed at improving strengths and eliminating weaknesses through external opportunities. In particular: the formation of new sales channels, expanding opportunities for external financing of enterprise development projects, signing new important contracts in the field of logistics, creating effective marketing communications and management training. Much attention should be paid to monitoring changes in consumer tastes and preferences, the behavior of direct competitors and competitors producing substitute products, the price situation in the market. The company must pay attention to the negative factors caused by the pandemic, militarypolitical problems and instability of legislation.

\section{Conclusion and future work}

According to the results of the study we obtained the following generalizations.

The method of conducting SWOT analysis based on the formation of a basic set of indicators, selection of scientifically sound scales and the possibility of assessment taking into account the neutral, strong and weak action, which allowed to address the application of this model for continuous monitoring of the enterprise environment.

The selection of key indicators for assessing the impact of internal and external factor, which reduced the time for their formation. It should be noted that the proposed list of factors can always be supplemented by a market analyst and adapted for the analysis of enterprises taking into account industry characteristics.

It is determined that the estimation of weighting factors more than 20 indicators can be done only through the decomposition of factors in new subsystems. For this purpose, the following subsystems of internal environmental factors are identified: innovation and development, logistics, production, sales and promotion, enterprise finance, personnel management and subsystems of strategic and tactical management. And for the external environment two subsystems of factors: the intermediate environment and the macroenvironment. This allowed us to apply the method of pairwise comparisons by T. L. Saati to estimate the weights.

The proposed implementation of continuous monitoring of factors of neutral action cannot be ignored, because over time they can move to the category of both negative and positive factors.

Approbation of the proposed SWOT analysis methodology, carried out on the example of assessment of the environment of "Carlsberg", its capabilities and threats, allowed to identify measures to improve its activities, to 
Table 12. SWOT matrix of strategic decisions for public partnership "Carlsberg Ukraine"

\begin{tabular}{|c|c|c|c|}
\hline & & \multicolumn{2}{|c|}{ External factors } \\
\hline & & Threats & Opportunities \\
\hline \multirow[t]{2}{*}{ 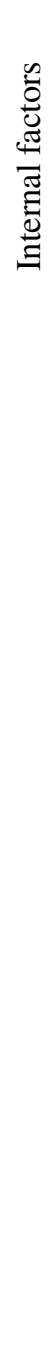 } & 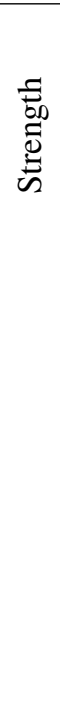 & $\begin{array}{l}S T_{1} \text { - vertical back integration strategy } \\
\text { (with suppliers); } \\
S T_{2} \text { - production of own raw materials; } \\
S T_{3} \text { - strategy of diversification of activ- } \\
\text { ity (focus on new types of low-alcohol and } \\
\text { soft drinks); } \\
S T_{4} \text { - flexible pricing policy for dealers } \\
\text { and agents; } \\
S T_{5} \text { - opening of own sales centers in re- } \\
\text { gional markets of the world; } \\
S T_{6} \text { - organization of cooperation with } \\
\text { trade representatives abroad; } \\
S T_{7} \text { - creation of more advanced types of } \\
\text { packaging and labels that would meet the } \\
\text { new requirements of consumers. }\end{array}$ & $\begin{array}{l}\mathrm{SO}_{1} \text { - formation of a new project team to address } \\
\text { issues of further diversification of the company; } \\
\mathrm{SO}_{2} \text { - development of new. more advanced types } \\
\text { of product packaging. which would correspond to } \\
\text { the best world analogues; } \\
\mathrm{SO}_{3} \text { - access to new competitive markets; } \\
\mathrm{SO}_{4} \text { - development of long-term partnerships } \\
\text { with suppliers of raw materials and equipment; } \\
\mathrm{SO}_{5} \text { - formation of new sales channels abroad; } \\
\mathrm{SO}_{6} \text { - interaction with leading research institutes } \\
\text { and equipment manufacturers to update beer pro- } \\
\text { duction technologies; } \\
\mathrm{SO}_{7}-\text { interaction with universities and institutes } \\
\text { of Ukraine and the world to find new creative } \\
\text { workers; } \\
\mathrm{SO}_{8} \text { - involvement of partners in financing their } \\
\text { own projects. }\end{array}$ \\
\hline & 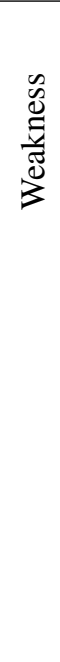 & $\begin{array}{l}W T_{1}-\text { monitoring the situation on the beer } \\
\text { market in Ukraine and the world; } \\
W T_{2}-\text { monitoring the desires and attitudes } \\
\text { of beer consumers; } \\
W T_{3} \text { - insurance and reinsurance of risks; } \\
W T_{4} \text { - entering the world market of new } \\
\text { types of premium products; } \\
W T_{5} \text { - creating more comfortable working } \\
\text { conditions in the company; } \\
W T_{6} \text { - intangible methods of staff reten- } \\
\text { tion. }\end{array}$ & $\begin{array}{l}W O_{1} \text { - training in advanced marketing technolo- } \\
\text { gies to promote products in regional markets } \\
\text { (trainings and seminars); } \\
\mathrm{WO}_{2} \text { - using of external sources to finance } \\
\text { projects to restructure the main business processes } \\
\text { of the enterprise; } \\
\mathrm{WO}_{3} \text { - development of partnerships with educa- } \\
\text { tional institutions to attract new employees; } \\
\mathrm{WO}_{4} \text { - involvement of SEO optimizers. content } \\
\text { managers. specialists in contextual and media ad- } \\
\text { vertising to improve search engine results abroad; } \\
\mathrm{WO}_{5} \text { - involvement of leading brewing laborato- } \\
\text { ries in the implementation of own projects; } \\
\mathrm{WO}_{6} \text { - sale of obsolete equipment; } \\
\mathrm{WO}_{7} \text { - strengthening the company's corporate } \\
\text { culture. }\end{array}$ \\
\hline
\end{tabular}

carry out quantitative and qualitative assessment of external and internal environment.

The use of the method of pairwise indicators and scientifically sound research scales of the SWOT analysis method allowed to significantly improve the quantitative assessment of indicators, to carry out a qualitative assessment of the results. But this technique will continue to be subjective, the success of which will always be derived from the analytical skills of those who build matrices and interpret indicators.

\section{References}

[1] L. Breiman, J. Friedman, C.J. Stone, R.A. Olshen, Classification and Regression Trees (Chapman and Hall/CRC, 1984)

[2] S.E. Jackson, A. Joshi, N.L. Erhardt, Journal of Management 29, 801 (2003)

[3] A.R. Ommani, African Journal of Business Management 5, 9448 (2011)
[4] B.S. Sigmon, Community and Economic Development Publications 16 (2014)

[5] S. Brad, E. Brad, Procedia Engineering 131, 616 (2015)

[6] E. Gürel, M. Tat, The Journal of International Social Research 10, 994 (2017)

[7] S. Ivanov, CEUR Workshop Proceedings 2422, 385 (2019)

[8] O. Kravchenko, I. Borisyuk, Z. Vakolia, O. Tretyak, O. Mishchenia, International Journal of Higher Education 9, 94 (2020)

[9] P. Mykhnenko, Ekonomycheskyi analyz: teoryia y praktyka 18, 60 (2015)

[10] V. Podgornov, Vestnik Adygeiskogo gosudarstvennogo universiteta. Seriia 5: Ekonomika (2012)

[11] C. Namugenyi, S.L. Nimmagadda, T. Reiners, Procedia Computer Science 159, 1145 (2019) 
[12] SuWaNu Europe, Report on SWOT and PEST analyses for implementation of reuse practices (2019), https://suwanu-europe.eu/ wp-content/uploads/2020/01/SWOT-PEST_ -Antwerp-and-Limburg.pdf

[13] J. Wang, Z. Wang, International Journal of Environmental Research and Public Health 17 (2020)

[14] J. Nazarko, J. Ejdys, K. Halicka, A. Magruk, Łukasz Nazarko, A. Skorek, Procedia Engineering 182, 482 (2017), 7th International Conference on Engineering, Project, and Production Management
[15] D. Pyzhlakov, Rossyiskoe predprynymatelstvo 6, 133 (2008)

[16] Y. Lozovik, T. Lozovik, Vcheni zapysky Universytetu KROK 20, 105 (2009)

[17] T.L. Saati, K.P. Kearns, Analytical Planning: The Organization of Systems (Pergamon, 1985), ISBN 008-032599-8

[18] A. Humphrey, SWOT Analysis for Management Consulting (SRI Consulting, 2005)

[19] PAT Karlsberg Ukraina (2021), https: //carlsbergukraine.com 